Revista Eletrônica Geografar, Curitiba, v. 2, Resumos do VI Seminário Interno de Pós-Graduação em Geografia, p. 15-15. Junho/2007

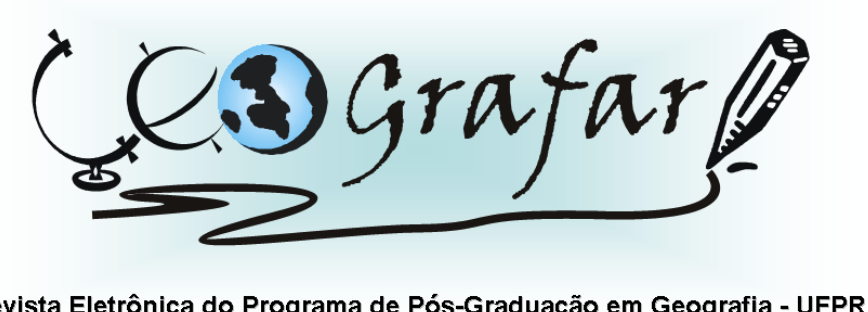

\title{
A CONTRIBUIÇÃO DAS ONGs AMBIENTALISTAS NA PRESERVAÇÃO E CONSERVAÇÃO DOS RECURSOS HÍDRICOS DA REGIÃO METROPOLITANA DE CURITIBA - 1992 a 2006
}

\section{CLEUSA MARA WOLSKY CARNEIRO ${ }^{1}$}

Vários problemas ambientais afetam os recursos hídricos, dentre os que mais comprometem tanto a qualidade de vida, como a promoção do desenvolvimento sustentado de uma comunidade são: o assoreamento dos cursos fluviais, erosão das margens dos canais e planícies aluviais, poluição das águas e erosão das encostas. $\mathrm{O}$ acesso à água potável é um direito básico e, portanto, inerente a todos os seres humanos. A degradação dos recursos hídricos, de maneira geral, é uma afronta à dignidade humana, dignidade esta garantida constitucionalmente. Observa-se que os atores governamentais, em grande parte, encontram dificuldades em preservar e conservar os recursos hídricos, principalmente os destinados ao abastecimento de água potável à população. Surgiram no final do século XIX entidades sem fins lucrativos, cuja consolidação só ocorreu a partir de 1980, com o objetivo de serem catalisadoras dos movimentos e aspirações sociais e políticas da população brasileira. Assim, estas Organizações Não-Governamentais (ONGs), tornaramse ao longo do tempo mais ágeis e flexíveis no combate de quaisquer irregularidades que viessem afetar a sociedade em geral e, principalmente a partir da Rio-92, algumas voltaram-se para as questões ambientais. Este estudo visa analisar a importância da participação da sociedade civil nas questões relacionadas ao uso sustentável dos recursos hídricos situados na Região Metropolitana de Curitiba, pós Rio-92. Destacam-se como objetivos específicos: identificar e avaliar a contribuição das ONGs ambientalistas e seus respectivos envolvimentos nesta questão; identificar se atuam, de maneira sinérgica, com o governo e comunidades locais; examinar se estão preocupadas com a eficácia de seu trabalho e cientes de seu verdadeiro papel perante a sociedade. Para tal, inicialmente, será levantado o referencial teórico que embasará a pesquisa, tanto sob o ponto de vista metodológico, quanto conceitual. Posteriormente serão identificadas as ONGs que atuam na temática desse trabalho, para então serem contemplados os objetivos aqui propostos.

Palavras-Chaves: Recursos Hídricos- Desenvolvimento Sustentável- ONGs Ambientalistas

${ }^{1}$ Mestranda em Geografia - UFPR - email: cleusa.wol@hotmail.com Orientadora: SONY CORTESE CANEPARO 